\title{
COMBUSTION ANALYSIS OF D-LIMONENE AS AN ADDITIVE TO DIESEL-BIODIESEL BLENDS IN COMPRESSION IGNITION ENGINES
}

\author{
W. K. D. C. Saruhashi, \\ D. L. Módolo, \\ L. E. R. Pereira, \\ and L. F. Micheli
}

Universidade Estadual Paulista

Departamento de Engenharia Mecânica

Faculdade de Engenharia

Bairro Vargem Limpa

CEP. 17033-360, Bauru, São Paulo, Brasil williankeniti92@gmail.com delsonmodolo@feb.unesp.br

luizeduardo@feb.unesp.br luisfrancisco.micheli@gmail.com

Received: June 15, 2018

Revised: August 20, 2018

Accepted: February 12, 2019
ABSTRACT

Vegetable oils, when subjected to transesterification process generate "vegetable oils esters", with similar properties as density, cetane number, heating values, air-fuel ratio. However, problems resulting from the higher viscosity, leads to a worst spraying and combustion, formation of undesirable deposits on engine parts and contamination of the lubricant oil. Due to these problems, it is interesting to study an additive, also derived from biomass, to improve the characteristics of biodiesel for a suitable use in diesel engines. This paper proposes an additive (d-limonene obtained from orange peel) and preliminary results obtained from the tests in a stationary diesel engine fueled with mixtures of diesel/biodiesel/d-limonene, in different concentration to compare with a regular diesel-biodiesel blend and analyzes the influence of the additive on the combustion process. The diesel oil used was purchased from BR supply network (containing 7\% biodiesel in its composition) and two blends with different concentrations of the additive (1\% and 3\% of d-limonene) were prepared and tested. Diesel without additive was also tested. The effects of the DS10 addititivation with d-limonene in the combustion process of a diesel engine have been analyzed, the results obtained were satisfactory showing the positive effects in the combustion process with the addition of d-limonene in dieselbiodiesel blends, decreasing the ignition delay around 2 degrees and showing an improvement in the cetane number of the fuel.

Keywords: biodiesel; additive; d-limonene; combustion; diesel engine

\section{NOMENCLATURE}

ANG crank angle degree

CE Specific fuel consumption, $\mathrm{kg} /(\mathrm{kWh})$

DS10 S-10 diesel containing $7 \%$ biodiesel in its composition.

$\mathrm{D}+\mathrm{L} 1$ fuel blend containing $1 \%$ of d-limonene, in volume percentage

$\mathrm{D}+\mathrm{L} 3$ fuel blend containing 3\% of d-limonene, in volume percentage

$\mathrm{P} \quad$ in-cylinder pressure, bar

Q heat release rate, $\mathrm{kJ} / \mathrm{m}^{3}$

$\mathrm{T}$ exhaust gases temperature, ${ }^{\circ} \mathrm{C}$

TDC top dead center

SOC Start of combustion

SOI Start of ignition

\section{INTRODUCTION}

The use of vegetable oil as a fuel is not a recent idea. The compression ignition engine created by Rudolf Christian Karl Diesel was developed with the concept of using vegetable oil. Owing to the abundance and the affordable price of petroleum derivatives at the time, such a concept did not succeed.

With the increased demand for liquid fuels, concerns about environmental issues, and oil crisis that began in the 1970s lead to the search for alternative energy, including renewable fuels.

A number of researches showed that vegetable oil can be used in diesel engines (Almeida et al., 2002; Altin et al., 2001; Bari et al., 2002). Due to physical and chemical differences between diesel fuel and vegetables oil, it would be necessary to modify the engines to use these alternative fuels.

The vegetables oils after being subjected to transesterification process, generate "vegetable oil esters" (biodiesel), with properties similar to diesel oil, and could be used as without any modification (Buyukkaya, 2010; Canakci, 2007; Özener et al., 2014; Qi et al., 2010a; Qi et al., 2009b; Tüccar et al., 2014). However, problems resulting from the higher viscosity and others inherent to vegetable oil result in worst pulverization and combustion.

This scenario justifies the investigation of additives, also derived from biomass, to improve the combustion quality of diesel engines. In this work was realized an analysis of the effect of d-limonene on combustion process, as an additive to diesel/biodiesel blends. D-limonene is a terpene extracted from orange peel during the juice production process in industries.

\section{EXPERIMENTS}

In this study was used a stationary generator set of the brand Branco, model BD-4000CFE, equipped 
with manual and electric start. The engine is a single cylinder, air-cooled, direct injection, four-stroke diesel engine, $5.12 \mathrm{~kW}$ (rated power), 0.296L (displacement volume), $72 \mathrm{~mm}$ (bore) by $62 \mathrm{~mm}$ (stroke) and 102mm connecting rod length.

The coupled generator is single phase type, with $110 \mathrm{~V} / 220 \mathrm{~V}$ output voltage, rated speed of 3600 rpm, $60 \mathrm{~Hz}$, maximum power of $3300 \mathrm{~W}$ (3.3 kVA), rated power of $3000 \mathrm{~W}$ (3.0 kVA).

The load on the engine was realized by installing a Resistive Bench equipped with 10 halogen lamps of 500W each one, having a capacity to dissipate a rated power of up to $5 \mathrm{~kW}$.

An AVL piezoelectric pressure transducer, model GH14DK, was installed in the engine combustion chamber for monitoring the in-cylinder pressure, connected to the AVL Indicating Data Acquisition, model FlexIFEM Indi 601, which is a complete combustion measurement device, combining signal amplification and data acquisition.

A trigger wheel type "60-2" was installed on the engine crankshaft, combined with an inductive sensor connected to AVL Pulse Conditioner Box 389, that converts analog signals to digital signals, and send to the AVL Indicating Data Acquisition system to obtain the crankshaft position.

The exhaust gas temperature was measured by a Type $\mathrm{K}$ thermocouple installed in the exhaust pipe close to the engine cylinder head and was read in automotive multimeter of the brand Instrutherm.

A Mariotte Bottle was placed in a bench scale with $10 \mathrm{~kg}$ capacity and $1 \mathrm{~g}$ resolution, of the brand Digi-Tron. In this way, it was possible to determinate the fuel flow, and then, calculate the specific consumption.

The S-10 diesel oil used was purchased from the BR supply network. According to Petrobras, this fuel is sold containing $7 \%$ biodiesel in its composition. Two blends with different concentrations of the additive were prepared, $\mathrm{D}+\mathrm{L} 1$ containing $1 \%$ of $\mathrm{d}$ limonene and D+L3 3\% of d-limonene, in volume percentage. Diesel without additive was also tested and represented as DS10 in the results.

The tests were performed varying the load dissipated by the resistive bench in the conditions of 500W, 1000W, 1500W, 2000W, 2500W and 3000W, the pressure data acquisition will be presented only the results obtained with the load of $3 \mathrm{~kW}$, which is the critical condition of the experiments performed.

\section{RESULTS AND DISCUSSION}

The results obtained in the tests was represented in graphical form.

Figure 1 shows the in-cylinder pressure variation with crank angle. For D+L3, peak pressure is higher. The combustion starts closer to the top dead center (TDC), the rate of increase in pressure is higher and the deviation in the pressure curve is smaller during ignition delay compared to the other blends. This means that the ignition delay has decreases with the addition of d-limonene, confirmed by Fig. 2 which proves that D+L3 starts the combustion earlier than the others blends and the peak heat release is lower compared with DS10, what is expected because of the shorter delay ignition.

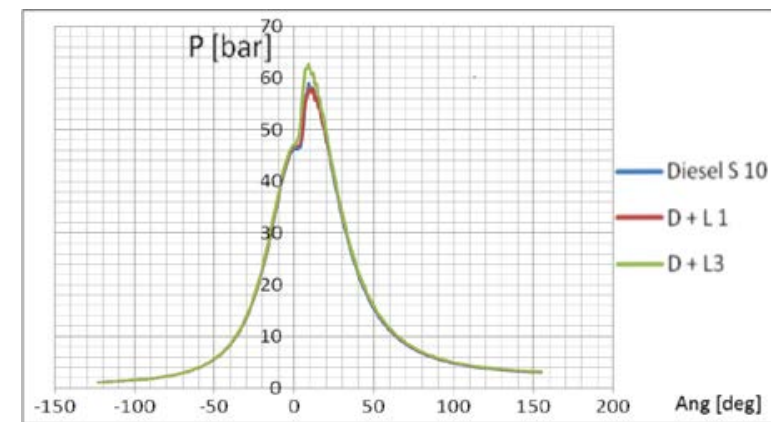

Figure 1. In-cylinder pressure versus crank angle.

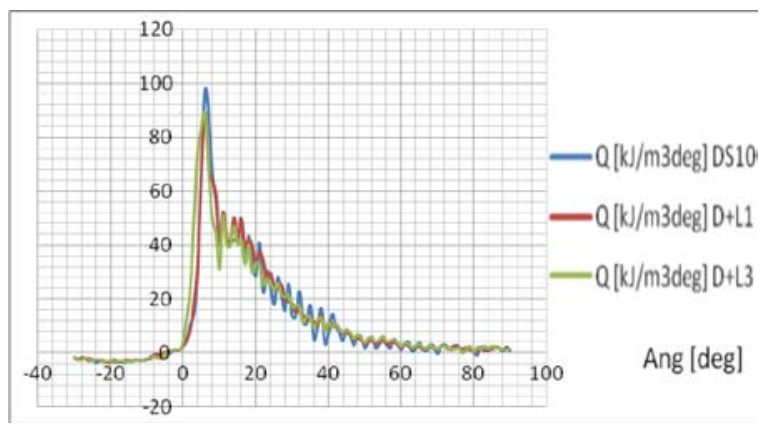

Figure 2. Heat release rate versus crank angle.

The burned fuel fraction values obtained from the experiments are shown in Fig 3. The observed negative values occur due to vaporization of the fuel, after the start of injection (SOI), with the start of combustion (SOC) the burned fuel fraction values increase and become positive. As can be seen the combustion starts earlier for D + L3 in relation to the two other blends, decreasing the ignition delay around 2 degrees according to the graph.

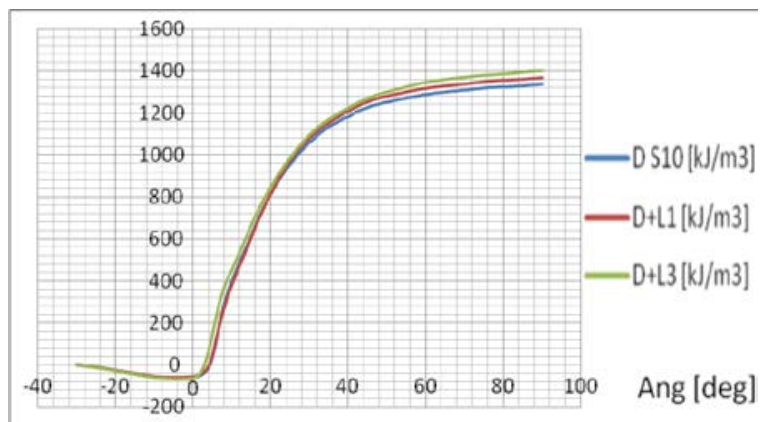

Figure 3. Burned fuel fraction versus crank angle.

The pressure-volume diagram is shown in the Fig. 4. An identical behavior could be observed for DS10 and D+L1. With a higher concentration of d- 
limonene than the other two blends, there is an increase in the pressure peak for D+L3.

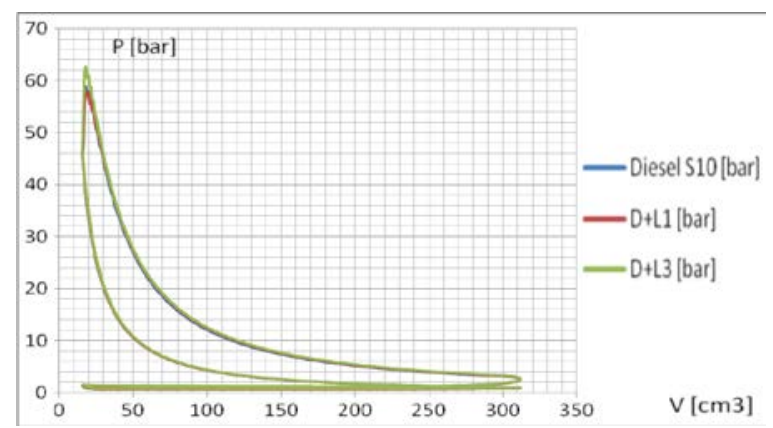

Figure 4. Cylinder pressure versus volume.

The analysis of the 4 figures above shows that the additivation of the DS10 with d-limonene decreased the ignition delay and increased the cetane number.

The exhaust gases temperature, Fig. 5, and specific consumption, Fig. 6, did not show significant differences between the three blends.

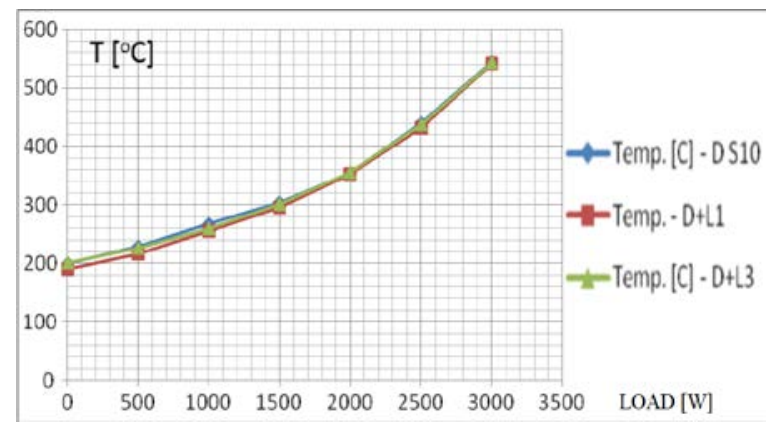

Figure 5. Exhaust gases temperature versus engine load.

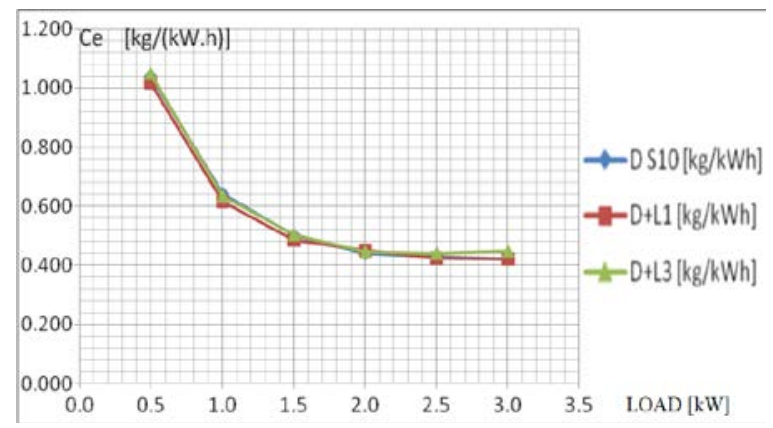

Figure 6. Specific fuel consumption versus engine load.

\section{CONCLUSIONS}

The effects of the DS10 addititivation with dlimonene in the combustion process of a diesel engine have been analyzed. The graphs obtained from the tests performed showed a decreased in ignition delay around 2 degrees, and an improvement on the cetane number of the fuel with the d-limonene addition.

The results obtained were satisfactory showing the positive effects on combustion process with the addition of d-limonene in diesel-biodiesel blends, which makes interesting to test other formulations with higher amounts of d-limonene to achieve more conclusive results regarding their effects on combustion process in diesel engines.

\section{ACKNOWLEDGEMENTS}

The authors thanks the "Fundação de Amparo à Pesquisa do Estado de São Paulo” - FAPESP, for funding this work through process number 2014/12107-7.

The authors also thanks CAPES for their financial support.

\section{REFERENCES}

Almeida, S. C. A., Belchior, C. R., Nascimento, M. V. G., Vieira, L. S. R., and Fleury, G., 2002, Performance of a Diesel Generator Fuelled with Palm Oil, Fuel, Vol. 81, pp. 2097-2102.

Altin, R., Çetinkaya, S., and Yücesu, H. S., 2001, The Potential of Using Vegetable Oil Fuels as Fuel for Diesel Engines, Energy Conversion and Management, Vol. 42, pp. 529-538.

Bari, S., Lim, T. H. and Yu, C. W., 2002, Effects of Preheating of Crude Palm Oil (CPO) on Injection System, Performance and Emission of a Diesel Engine, Renewable Energy, Vol. 27, pp. 339-351.

Buyukkaya, E., 2010, Effects of Biodiesel on a DI Diesel Engine Performance, Emission and Combustion Characteristics, Fuel, Vol. 89, pp. 30993105.

Canakci, M., 2007, Combustion Characteristics of a Turbocharged DI Compression Ignition Engine Fueled with Petroleum Diesel Fuels and Biodiesel, Bioresource Technology, Vol. 98, pp. 1167-1175.

Özener, O., Yüksek, L., Ergenç, A. T., and Özkan, M., 2014, Effects of Soybean Biodiesel on a DI Diesel Engine Performance, Emission and Combustion characteristics, Fuel, Vol. 115, pp. 875-883.

Qi, D. H., Chen, H., Geng, L. M., and Bian, Y. Z. H., 2010a, Experimental Studies on the Combustion Characteristics and Performance of a Direct Injection Engine Fueled with Biodiesel/Diesel Blends, Energy Conversion and Management, Vol. 51, pp. 2985-2992.

Qi, D. H., Geng, L. M., Chen, H., Bian, Y. Z. H., Liu, J., and Ren, X. C. H., 2009b, Combustion and Performance Evaluation of a Diesel Engine Fueled with Biodiesel Produced from Soybean Crude Oil, Renewable Energy, Vol. 34, pp. 2706-2713.

Tüccar, G., Tosun, E., Özgür, T., and Aydin, K., 2014, Diesel Engine Emissions and Performance from Blends of Citrus Sinensis Biodiesel and Diesel Fuel, Fuel, Vol. 132, pp. 7-11. 